RACE, IMMIGRATION, GENDER, AND THE POLITICS OF EXCLUSION

\title{
Making Migrants "Criminal": The Mariel Boatlift, Miami, and U.S. Immigration Policy in the 1980s
}

\author{
Alexander M. Stephens \\ University of Michigan, US \\ amstep@umich.edu
}

In 1980, nearly 125,000 Cubans sailed to Florida in the mass migration now known as the Mariel Boatlift. They arrived amidst reports that Cuban officials had released many of them from prisons and forced them onto boats bound for the United States. A significant minority of these "Mariel Cubans" had been incarcerated at some point in the past, but press accounts often distorted their stories and they entered a United States with a growing anti-immigrant movement that contributed to a largely hostile reception. While many Mariel Cubans eventually became incorporated into the established South Florida Cuban community, some continued to struggle to find their way. The focus of this article is on this latter group. It reveals the exclusionary and punitive dynamics that emerged in response to them in Miami and how the resulting demands for policy change were scaled up by elected officials to shape developments at the federal level that ultimately made "criminals" out of a much broader group of people who crossed U.S. borders in the 1980s and beyond.

Keywords: Mariel Boatlift; Cubans; migration; criminalization; policing; race; law

On May 6, 1981, the Democratic Governor of Florida testified before Congress with a clear message for the federal government: get rid of them. Bob Graham went to the U.S. Capitol that day for a rare joint hearing held by House and Senate subcommittees on immigration to discuss the final report of the Select Commission on Immigration and Refugee Policy. The Commission began two years prior, under the Carter administration, in response to calls to reform U.S. immigration laws. The members of the Commission had begun their work amidst the arrival of hundreds of thousands of Southeast Asian refugees and a growing anti-immigrant movement. Representatives from the agribusiness industry and labor unions-traditional stakeholders in immigration policy debates-spoke on the first day of hearings. Yet Florida Governor Graham was the first elected official to testify. "We cannot subsidize fail[e]d foreign societies and their undesirables with a policy that declares in effect anyone who can land their feet on the sands of Florida's beaches has permanent license to run through Florida's streets," he said (Final Report of the Select Commission 116). "Since the Federal Government was unwilling to enforce the immigration laws when illegal criminal aliens entered our country last summer," he continued, "it must take responsibility for expelling those individuals now." Graham insisted that local communities should not be forced to bear "an unduly harsh burden" or "pick up the slack for Federal inattentiveness." In sum, he said, "We cannot allow our Nation to lose control of its borders" (117).

Graham clarified that his words did not apply to "all" immigrants. He had a specific group in mind, a particular contingent of the 125,000 Cubans who had entered the United States the previous Spring and Summer in a mass migration now known as the "Mariel Boatlift." Although most of the newcomers were "law- abiding refugees," he claimed, there were "many known criminals who illegally entered this country" (117). In fact, the "Mariel Cubans" had left home under a wide range of circumstances. A significant group wanted to reunite with relatives in the United States. Some were prominent dissidents. Many sought new political and economic circumstances. But the diversity of their experiences and motivations was obscured shortly after they began arriving in Florida and reports surfaced that the Cuban government was using the boatlift to transport people from its prisons to the United States. While often exaggerated, these were not 
empty rumors. There were people-well over 20,000 of them according to U.S. immigration authorities-who had spent time in prison at some point prior to joining the boatlift. ${ }^{1}$

Reporters and other observers in the U.S. distorted the stories of these formerly incarcerated Mariel Cubans. They rarely understood or bothered to interrogate the specific conditions and practices that had shaped their encounters with the Cuban criminal law enforcement system. Some had gone directly from prison cells to the Port of Mariel, but most were living back home after completing their sentences when they received a not-so-optional offer from the police to board a boat and leave the country. Federal officials determined that most of their past crimes were not serious enough to render them ineligible for admission to the United States. ${ }^{2}$ Yet, in the absence of consistent efforts to contextualize the experiences of formerly incarcerated Mariel migrants, a wave of sensationalist press coverage took over. Headlines in Miami papers and around the country highlighted alleged crimes committed by Mariel Cubans after they arrived. By the end of the summer of 1980, what the press initially deemed the "Freedom Flotilla" had been reimagined as an invasion. ${ }^{3}$

Media figures, elected officials, and established communities in South Florida tended to read the newcomers as threats rather than as people worthy of protection. That perception did not owe solely to reports about their criminal pasts. The social positions of many of the Mariel Cubans made them particularly susceptible to harsh treatment and coercive policies. First, in contrast with other recent groups of Cuban migrants, the boatlift arrivals reflected the large population of people of African descent in Cuba. Estimates of their share of the boatlift vary widely. ${ }^{4}$ The uncertainty reflects the complexity of racial categories, which only expands as groups migrate and move from one social context to another. However, a survey of their immigration records suggests that the terms "Black" or "mulato" could be applied to at least 30 percent of Mariel arrivals, who either identified themselves using one of these categories or were assigned to one of them by the people filling out their forms. ${ }^{5}$ Longstanding associations of Blackness with criminality in both Cuba and the United States underpinned the sense among many in South Florida that the bulk of the newcomers were "just a bunch of criminals." Mariel Cubans also entered the U.S. amidst media reports that upwards of twenty thousand of them were "homosexuals." These accounts almost certainly exaggerated the numbers, but they ran parallel to very real stories of the experiences of queer Mariel Cubans who had been targeted by police and incarcerated on the island. ${ }^{7}$ In addition to eliciting homophobic reactions, such coverage likely deepened the impression that many of the newcomers were people with "criminal" pasts. Finally, a disproportionate number of the people who made the voyage from Mariel to Key West were young single men, a group rarely imagined to be particularly deserving of a humanitarian approach and often seen as prime suspects for illicit activity. ${ }^{8}$ Combined with reports that many of them had come out of Cuban prisons, these traits marked the newcomers as especially unwelcome additions in many U.S. communities. Jorge Duany notes that, in the aftermath of the boatlift, participants in a 1981 national Gallup poll ranked Cubans as the second least "desirable" neighbors a person could have. Only one group fell below them in the survey results: "religious cult members" (81).

The Mariel Cubans differed from the established Cuban community in Miami in at least one other crucial way. Unlike most of their compatriots in the United States, very few boatlift arrivals initially benefitted from the programs and policies that had been developed to support Cuban refugees over the previous two decades. The Refugee Act of 1980, approved by Congress just one month before the Mariel Boatlift began,

\footnotetext{
1 See Clark et al. p. 7.

2 See Clark et al. p. 7

3 See Hufker and Cavender.

${ }^{4}$ See García p. 68.

${ }^{5}$ See Bach et al. pp. 33-35. Any analysis of racial dynamics requires using contested and often fraught terms that have been adopted by and/or imposed on a diverse group of people in distinct ways across time periods and geographic regions. In this article, when discussing Cubans, I use the English term "Black" and the Spanish term "mulato" to denote the two most common categories used in Cuba to describe someone, or identify oneself, as a person of African descent. I use "Black" and "White" as modifiers to describe most groups in the United States. When it is necessary to differentiate White Cubans and Cuban Americans from others typically categorized as "White," I follow the convention in South Florida and use the term "Anglo" to discuss the latter group.

${ }^{6}$ See J. Silva and Dubocq. Also, on race and criminalization in twentieth-century Cuba, see de la Fuente and Bronfman. On similar dynamics in the United States, see Stabile and Muhammad.

7 See Peña pp. 47-51; Capó, Jr. pp. 86-90.

${ }^{8}$ See Bach et al. pp. 33-37; and Rios. Lipman contrasts the criminalizing depictions of Mariel Cubans held at Fort Chaffee, Arkansas, with media accounts of Vietnamese refugees detained at the same site five years earlier. Lipman notes that the press tended to emphasize the stories of women and children among this earlier group and often depicted them as "vulnerable victims" in need of U.S. protection (63).
} 
established strict criteria for grants of asylum and introduced additional specifications for the discretionary legal mechanism known as "parole," which had been invoked by multiple presidential administrations since the early-1950s to permit the ad hoc admission of hundreds of thousands of people as refugees ("Immigration and Nationality Act" 188). The new legislation stipulated that the executive branch could use parole to allow large groups to enter the U.S. and exceed the annual refugee admissions cap of 50,000 if "an unforeseen emergency refugee situation" led the White House to determine that it was "justified by grave humanitarian concerns" or "otherwise in the national interest" ("Refugee Act" 103). According to senior administration officials interviewed by scholars Gil Loescher and John A. Scanlan, Carter chose not to exercise this provision in the summer of 1980 because he did not want to "reward illegal entry" or "set a dangerous precedent" by granting de facto refugee status to Mariel Cubans and thousands of Haitian asylum seekers who were arriving by boat in Florida during the same period (Loescher and Scanlan 185). Instead, the administration paroled the new arrivals and assigned them to a provisional category created specifically for them: "Cuban-Haitian entrants (status pending)." This temporary permission to remain in the U.S. had to be renewed by Congress after six months and it meant that, at first, almost none of the newcomers from either country qualified for typical refugee benefits. Most of the Mariel Cubans would eventually get substantial federal support and the chance to apply to become permanent residents, but the financial assistance initially available to them was a fraction of what most of their predecessors had received, and their permission to live in the United States remained tenuous for years. ${ }^{9}$ Their irregular status, combined with negative perceptions of the boatlift, also made them vulnerable to the charge that, since they were not "refugees," they ought to be viewed as "illegal immigrants." ${ }^{10}$

Legal scholars have written extensively about the increasingly expansive system for criminalizing and policing migrants, sometimes referred to as "crimmigration," which emerged in the 1980s (Stumpf, "The Crimmigration Crisis"). Such work frequently cites laws from the mid-eighties as origin points but tends to focus on later developments at the federal level. ${ }^{11}$ While essential, studies of federal processes are not always able to capture debates surrounding migrants at the municipal, state, and regional scales. Yet it was these developments, which began earlier, that generated much of the momentum behind eventual changes in national policy. ${ }^{12}$

At the center of this article is a set of dynamics surrounding a small group of migrants at the local and state levels that contributed to major changes in U.S. immigration policy. Although many Mariel Cubans eventually became incorporated into South Florida Cuban communities, some struggled to find their way. ${ }^{13}$ The focus of this article is on the impact of this latter group, made up not of "typical" Mariel Cubans but of "the most marginal of the marginal" (Peña 62). A number of scholars have written about the initial confinement of boatlift arrivals on U.S. military bases or focused on the indefinite detention of Mariel "excludables" in federal prisons, but relatively little attention has been dedicated to the intermediate experiences of many of those same people as they were released into U.S. communities and faced surveillance and policing amidst increasingly harsh crime policies and an expanding migrant restriction regime. ${ }^{14}$ Casting them as "criminals" helped drive efforts to police and confine them. Their presence in jails and prisons, in turn, became an impetus for more punitive policies, which ultimately reshaped the U.S. approach to a far larger set of noncitizens. Over the course of the 1980s, policymakers scaled up the approach developed for this group in Miami. State and federal representatives from Florida took what they had seen to Washington,

\footnotetext{
${ }^{9}$ See Bon Tempo p. 183. Although earlier groups of Cubans also typically entered the U.S. via parole, their permission to be in the country did not come with an expiration date, and most received substantial federal assistance upon arrival through the Cuban Refugee Program. After 1966, Cubans paroled into the U.S. were eligible for an expedited path to permanent residency thanks to the Cuban Adjustment Act. The vast majority of Mariel Cubans did not qualify for refugee assistance when they first arrived and they did not benefit from the Cuban Adjustment Act until 1984, when Ronald Reagan's Department of Justice-in the face of a pending lawsuit by boatlift arrivals-determined that they were, in fact, eligible to adjust their status under the existing law. Haitians who arrived during the same period remained in limbo for two additional years. See Pear.

10 See Rose.

11 See Chacón; García Hernández.

12 Several years before the emergence of the term "crimmigration," Miller described this criminalizing turn in U.S. immigration law in an article that attended to some of these earlier, regional developments. In fact, Miller cited "reports of high crime rates-particularly drug-related crimes-among Miami's Mariel Boatlift refugees" as a major cause of "rising public concern about the criminality of illegal immigrants and refugees" (626). Legal scholars have devoted a great deal of attention to the relationships among municipal and state laws, local police, and federal immigration enforcement but usually with a focus on more recent periods. See, for example, Rodríguez; Stumpf; Motomura; Cox and Miles; Lai.

13 See García pp. 115-17.

14 See Hamm; Kahn; Dow; Lipman; Guerrero; Loyd and Mountz; Young; Shull.
} 
where they connected their concerns and demands to those of colleagues from other key cities, states, and regions. As a result, immigration enforcement agencies began to expand the scope of their operations from their traditional center along the Mexico-U.S. border. By the end of the decade, U.S. immigration policy would acquire a sharper focus-both in rhetoric and in law-on noncitizens charged with or convicted of offenses in the criminal legal system.

Local appeals for action after the Mariel Boatlift created long-lasting echoes in Washington and contributed decisively to the growth of an integrated regime of immigration and criminal law enforcement during the Reagan years and beyond. This was the result of a fully bipartisan effort. When Bob Graham, a Democrat, spoke before Congress in 1981, his comments about "known criminals who illegally entered this country" emphasized local conditions in Miami and the alleged criminality of Mariel Cubans. Yet his testimony became part of a chorus of calls by elected officials from multiple states and both major political parties to punish and deport noncitizens who violated criminal laws. This convergence helped drive a burgeoning political consensus regarding the "problems" of unauthorized immigration, crime, and illicit narcotics. As lawmakers backed the War on Drugs and adopted a "get tough" approach, they also began to expand on the racialized labor control framework that had been cultivated in the Mexico-U.S. borderlands by embracing a model that emphasized crime control and "border security." 15 The rhetorical slippage evident in Graham's testimony foreshadowed this shift. Graham named "illegal criminal aliens" as the imagined targets of new federal policies. In doing so, he elided familiar language about "illegal aliens" with what was then a relatively obscure term: "criminal alien."16

To understand the bipartisan project that reoriented U.S. policy around the figure of the "criminal alien," it is necessary to get beneath federal legislation and examine how developments in key sites around the country drove changes later visible at the national level. ${ }^{17}$ One of those places, without question, was Miami in the aftermath of the Mariel Boatlift. At the center of punitive responses to the boatlift in South Florida was a group of Cubans whose experiences with police and prisons were invoked by policymakers in processes that increasingly made "criminals" out of a much broader group of people on the move.

\section{Welcome to Miami}

Understanding how Mariel Cubans became archetypical "criminal aliens" requires an exploration of the dynamics surrounding their arrival in South Florida in 1980. That spring, thousands of Cubans began boarding boats at the Port of Mariel and sailed north to Key West. The mass migration was the Cuban government's solution to a series of crises that reached a climax in April, when 10,000 people rushed the grounds of the Peruvian Embassy in Havana hoping to gain permission to leave the country. That left U.S. President Jimmy Carter caught between his support for the Refugee Act-a new law designed to standardize and limit refugee admissions-and fears of election-year blowback among Florida Cubans should he turn away people still widely perceived as victims of communism and worthy of protection. Television news coverage initially featured images of relieved and gleeful people stepping off boats. One shot featured an elderly Cuban woman sitting in a chair in the Key West sunset, another captured a group of people gathered around a man with a guitar and singing "Amazing Grace" in Spanish while they waited for more people to arrive at the docks. In the words of the reporter, "By the hundreds, the abuelas-the grandmothers-the niños-the babies-the seekers and hopeful arrive" (McFarland 25 Apr.). Commentators deployed well-worn Cold War language about people who left countries with socialist governments. Conservative columnist George Will proclaimed that the Cuban migrants were "a resource more precious than all the oil under Saudi Arabia" (Will). Jimmy Carter himself famously declared that the United States would "provide an open heart and open arms to refugees seeking freedom from Communist domination and from economic deprivation, brought about primarily by Fidel Castro and his government" (Carter).

\footnotetext{
${ }^{15}$ See Hinton; Kohler-Hausmann; Lytle Hernández, Migra!; Loyd and Mountz; Goodman.

${ }^{16}$ Lytle Hernández has shown that the INS Border Patrol began to emphasize the term "criminal aliens" in the 1950s to focus public attention on the alleged role of migrants in the narcotic trade, but the strategy does not appear to have gained traction among the legislators or the broader public until later (Migra! 205-12). Felker-Kantor describes a dynamic in Los Angeles that was similar in some ways to the one I explore in Miami during roughly the same period (162-63). There were precedents for the effect of the Mariel Boatlift on U.S. attitudes about noncitizens and crime. Goodman suggests that key moments in the intervening decades had a "lasting impact" on the "criminalization of migrants," including Operation Intercept in 1969, when federal agencies "searched all northbound vehicles for contraband marijuana," effectively treating all Mexican travelers as potential drug smugglers (110).

${ }^{17}$ Historians of immigration have looked to the local and state levels to make sense of the origins and evolution of immigration law enforcement, though much of this work has focused on earlier periods in U.S. history. See Lytle Hernández, Migra!; Parker; Hirota.
} 
Even before Carter uttered those words, however, representations of the newcomers in the Miami area had become far less celebratory. The local press began to report stories of strangers who had been forced onto boats sent to retrieve the relatives of Miami Cubans. Federal immigration agents told reporters that they had found murderers and other "criminals" among the new arrivals (Dewar). About ten days into the boatlift, longtime WTVJ anchor Ralph Renick delivered an editorial in which he warned that among those leaving Cuba were "Castro's problem people-killers, thieves, and others who have been in prison who are noncontributors and troublemakers." Although he concluded his spot by encouraging his viewers not to let the "clever bearded one" turn them "against the exile community," Renick conveyed that this group of Cubans was not like the ones that had come before-and that some of them might even try to kill you (Renick).

Whereas the Anglo-dominated press hammered the idea that the newcomers were "criminals," Cubans in Miami responded with ambivalence..$^{18}$ After an initial outpouring of support and a strong push to help their relatives and friends, the bulk of the Cuban community withdrew from the people arriving from Mariel. ${ }^{19}$ Cubans in South Florida were susceptible to the same fears that drove others' responses to reports that the Cuban government was using the mass emigration to "empty" prisons and mental institutions. In fact, thanks to their social networks and the exile press, many Miami Cubans likely had more exposure than other U.S. residents to the criminalizing language and images coming from Havana in the early days of the boatlift. ${ }^{20}$ Less than two weeks after people had begun leaving from Mariel, Fidel Castro gave a widely publicized speech in which he called them "delinquents" and "lumpen" (Bustamante 222-24). Despite the Cuban government's established pattern of deriding and discrediting those who left the country, it appears that this was one claim by Castro that many Cuban exiles were quick to accept as fact.

Miami Cubans began to distance themselves from the people who came in the boatlift. Sociologists Alejandro Portes and Alex Stepick have described this process as a "reactive formation" (Portes and Stepick 34). A community that had cultivated an identity closely associated with assimilation and economic success started to perceive the new arrivals as potential threats. Racial thinking decisively shaped this process. ${ }^{21} \mathrm{An}$ estimated 95 percent of the Cubans who entered the U.S. between 1959 and 1979 identified as White (García 68). While they initially encountered discrimination, most benefited from their proximity to Whiteness as it functioned in the United States. Yet their place within the country's racial order was "conditional" in ways that made many Cubans sensitive to changes that might undermine their collective position. ${ }^{22}$ An unnamed Cuban American official with the City of Miami spelled this out in an interview with Portes and Stepick: "Mariel destroyed the image of Cubans in the United States and, in passing, destroyed the image of Miami itself for tourism. The marielitos are mostly Black and mulattoes of a color that I never saw or believed existed in Cuba. They don't have social networks; they roam the streets desperate to return to Cuba" (qtd. in Portes and Stepick 21). The official highlighted the newcomers' race, their lack of connections in Miami, and his perception that they were somehow sympathetic to the post-revolutionary system to mark them as undesirable and, in effect, inauthentic Cubans. The efforts of earlier arrivals to distance themselves from the newcomers became especially urgent in the face of evidence that the political power Cubans had begun to acquire in South Florida was in jeopardy. An Anglo-led campaign to repeal the local Bilingual-Bicultural Ordinance in the fall of 1980 rolled back one of the first major political victories of Miami Cubans in what many understood as a direct response to the Mariel Boatlift. ${ }^{23}$ To solidify their own inclusion, however, members of the established community drew on well- established patterns of racial thinking to contribute to the exclusion of their newly arrived compatriots.

\footnotetext{
${ }^{18}$ See Gosin pp. 66-67.

${ }^{19}$ A small group of Cuban exiles and migrants, including Siro del Castillo, consistently advocated for Cubans who arrived in the boatlift. Del Castillo defended Mariel Cubans who had been subject to the most intense forms of scrutiny and scorn by the established Cuban community in South Florida, government officials, and the mainstream press. He worked closely with them as director of the makeshift Krome Avenue detention site for Cubans and Haitians in 1980 and at the "resettlement camp" at Fort Chaffee, Arkansas. He went on to publish a trenchant critique of "the irresponsible and sensational myths" being told about the people who had arrived in the boatlift (del Castillo 7).

${ }^{20}$ See Sierra Madero.

${ }^{21}$ The disparaging nickname "marielitos" almost certainly reflected racial dynamics between Miami Cubans and the newcomers. Given the discrepancy between the racial composition of the two groups, it is hard to ignore the resonance of "marielito" with the Spanish term, "negrito." While meanings of the latter term vary, White Cubans tended to deploy it to condescending effect. The fact that similar nicknames did not emerge for earlier groups of Cuban exiles and migrants is further indication of the stark line that "pre-Mariel" arrivals drew between themselves and the newcomers.

22 See Mirabal p. 373.

${ }^{23}$ See García p. 74.
} 
The historical relationship between race and migration patterns had serious consequences for Mariel Cubans. The Carter administration prioritized the resettlement of people who had family members ready to care for them in the Miami area. Local and federal officials screened roughly half the boatlift arrivals in processing centers in South Florida and quickly released them to relatives. The federal government sent those without such connections, about 62,000 people, to temporary processing and detention centers-officially known as "resettlement camps"-at military bases around the country. The racial breakdown of these numbers reveals that White participants in the boatlift were significantly more likely to have family members in South Florida prepared to take them in. Only about 10 percent of Mariel Cubans processed and released in South Florida were Black or mulato. But they made up 50 percent of the people sent to camps at Fort Eglin, Fort Chaffee, Fort Indiantown Gap, and Fort McCoy. ${ }^{24}$ Once in the camps, Cubans of African descent had a harder time getting out. They first had to find a "sponsor" to agree to help them secure a job and a place to live. Resettlement agencies struggled to find sponsors willing to take Black or mulato Cubans into their home. ${ }^{25}$ During the summer, coverage of several "riots" at the camps-at least one of which began as a protest by boatlift arrivals over the unanticipated length of their confinement-hardened their criminal image and undermined resettlement efforts. ${ }^{26}$ Even so, most people sent to the camps were released to sponsors by the end of the summer. ${ }^{27}$

Upwards of 15,000 of those initially placed with sponsors elsewhere soon made their way to metropolitan Miami. They converged on a "no vacancy" city (Riviera). ${ }^{28}$ The rental vacancy rate in Miami hovered at about one-half of one percent, as developers sought profits in condominiums and luxury rentals rather than affordable housing. ${ }^{29}$ Just a few weeks into the boatlift, officials in the Office of Refugee Resettlement had noted that housing was becoming "an acute problem in the Miami area" and reported that they were "beginning to hear stories of people being temporarily housed in converted dog kennels" (Putnam). As the movement of migrants into South Florida continued over the summer, word got around that some of them were "sleeping on streets and pleading for food" (Stark). When relationships with sponsors broke down or migrants encountered financial problems, some ended up with little choice but to live outside. Local officials first responded to the growing population of houseless Cubans by bringing those without sponsors to the Orange Bowl, then home to the NFL's Miami Dolphins. ${ }^{30}$ With Fall football season approaching, city leaders decided to move the Orange Bowl residents to a temporary "Tent City" under an interstate overpass on the edge of downtown. ${ }^{31}$

For many Miamians, Tent City came to symbolize all that was wrong with the Mariel Cubans and the federal response to their arrival. Media outlets invoked the image of an undeserving "underclass" often used to disparage or dismiss African American communities and applied it to the Mariel Cubans (O'Connor 265-68). The Editorial Board of the Miami Herald proclaimed, "Only dramatic Federal action can avert ugly consequences from the dumping of these men into problem-plagued cities such as Miami. It's inconceivable that Governor Graham could nominate President Carter for re-election while the Administration ignores the hundreds of Cubans currently living in tents under an expressway in Little Havana." The Herald portrayed the residents of Tent City as lazy and undeserving of public funds-"able-bodied men by the hundreds" who spent their time "lounging on cots" ("Comprehensive U.S. Action"). Monika Gosin explains that, while these accounts almost never made explicit mention of racial categories, they employed coded language-including the term "ghetto"-to discuss this largely Black and mulato group of Cubans (Gosin 73-78). Gosin argues that negative media depictions of Mariel Cubans also reflected entrenched conceptual frameworks for dividing "good immigrants" from "bad immigrants" and "natives" from "foreigners." Multiple groups made use of these constructs to distinguish themselves from the boatlift arrivals, including some Black Miamians, whose own precarious situation in the city did not always lead to a sense of solidarity. ${ }^{32}$ For the newcomers in Tent City, this meant that there were few places to turn for community support.

\footnotetext{
${ }^{24}$ See Bach et al. p. 33.

25 See Hoeffel p. 47. The effects of racial bias in the sponsorship process became evident in the changing demographics of the camp population. Several months after the boatlift ended, at the end of January 1981, 73 percent of the 5,022 people held at the only camp still in operation were classified by U.S. officials as "male" and "black or mulatto." The following summer, "black" men made up 95 percent of the people still detained at the camp. See "Overview" 24; "Status Report - Fort Chaffee."

${ }^{26}$ See Gosin p. 74.

${ }^{27}$ See "Overview" pp. 10-11.

${ }^{28}$ Later estimates suggest that, in total, over 85,000 Mariel Cubans eventually ended up in Miami. See Duany 81.

${ }^{29}$ See Veciana.

${ }^{30}$ I follow Lytle Hernandez in using the term "houseless," rather than "homeless," to convey that these were people experiencing a lack of permanent shelter, not people without homes. See City of Inmates Chapter 2.

31 See Hardman.

32 See Gosin pp. 49-54, pp. 91-104.
} 
The South Florida press merged accounts of supposed loafing with persistent reports of the allegedly criminal behavior of Mariel Cubans. Some residents followed suit. In a June 4 letter to the editors of the Miami Herald, Anne B. Hartzell of North Miami asked, "Why don't you tell it like it is?" Hartzell continued:

Most Anglos are middle- to lower-class whites who try to survive from one paycheck to the next. Why is the little man now forced to support 70,000 more Cubans? I've seen the 'Tent City' of homosexuals, mental patients, and criminals. Look at The Herald article on the hundreds of angry Cuban refugees who jumped the fence at Eglin [Air Force Base]. What are they gong [sic] to do when unleashed on us after Eglin? Burn and loot? They have boasted they want cars, TVs, beautiful clothes, and "freedom to protest." Who cares about middle-aged white women trying to be self-supporting rather than receiving food stamps and welfare-and the elderly on fixed incomes? I go into a store, trying to spend less than $\$ 20$ a week on groceries, and I'm behind a Cuban with three carts full of food I cannot afford-and I'm supposed to support them? By God, I refuse to do it!

Hartzell's comments encapsulated the notion that the boatlift arrivals were unworthy of public assistance; her words also exemplified the racialized and pathologizing claims used to justify that position.

Cubans who were already established in Miami expressed related concerns about this subset of newcomers, albeit often in more measured language that sought to turn attention to some of their seemlier compatriots. Carlos J. Arboleya, a prominent Cuban-born bank president in Miami, wrote a guest article for the Miami Herald in which he emphasized the economic contributions of Cubans who had made their way to South Florida. He also attempted to offer context for Mariel Cubans who had spent time in jail or prison prior to leaving the island, suggesting that most had been convicted of violations such as "refusing to work in sugarcane fields for the revolution, stealing a shirt, traveling without a permit from one town to another to be with a pregnant wife as she gave birth, trying to leave the country on a boat, being disliked by the local vigilante committee, stealing food to eat and refusing to go to an official parade" (Arboleya). Some of these offenses, including petty theft, were among those most often listed by Mariel arrivals who admitted that they had been incarcerated in Cuba. ${ }^{33}$ Other transgressions detailed by Arboleya, while probably accurate, were less typical anecdotes that he clearly selected to elicit sympathy from readers. In any case, he made no effort to defend the people he saw as truly "undesirable," a term often deployed to describe the Mariel Cubans living in Tent City and on the streets of Miami. Arboleya claimed that Fidel Castro had "infiltrated the new immigrants with sufficient numbers of undesirables and Communist agents to lower the refugees' over-all prestige and respect." He called for their deportation and insisted that "[t]he Cuban-American community is just as concerned about this problem as non-Latins" (Arboleya). This concern, informed by perceptions of the race, sexuality, political leanings, and criminal histories of the newcomers, stemmed to a large extent from Miami Cubans' fears that the latest arrivals threatened to "tarnish their reputation" (Pedraza 155).

Anxiety and resentment contributed to these views of Anglos and Miami Cubans more than evidence. Although about 20 percent of all Mariel migrants admitted to having spent more than 15 days in prison while in Cuba, immigration authorities concluded that a very small fraction-less than 1.5 percent of the total boatlift population-had been imprisoned for offenses that the agency considered serious enough to make them ineligible for entry to the United States. ${ }^{34}$ The local press uncritically cited police statistics in stories about supposed links between Mariel Cubans and increases in crime, but subsequent analyses undermined the case that this group was distinctly prone to engage in illegal activity. ${ }^{35}$ While violence in Miami did increase after their arrival, this represented the continuation of an existing pattern rather than a new

\footnotetext{
33 See "Overview" p. 8.

${ }^{34}$ The number of people who had some experience of confinement in a juvenile detention center, jail, labor camp, or prison may have been higher. Carter administration officials in the Cuban- Haitian Task Force acknowledged that, since the INS generally did not have access to records from the Cuban government, their estimates reflected only what agents could gather from Mariel Cubans themselves. In one report, a high-level Task Force official conceded that "[t]he exact number is impossible to determine" and the number of people who had been in jail or prison at some point in the past likely exceeded the roughly 24,000 who admitted to having been confined for a period lasting longer than 15 days. See "Overview" p. 8. Cuban scholars have suggested that the number of formerly incarcerated people among the Mariel arrivals may have been higher than what the INS reported. Drawing from a random sample of records of 5,264 Mariel migrants from the Dirección Nacional de Inmigración (National Directorate for Immigration), Rafael Hernández and Redis Gomis determined that over 45 percent of the total boatlift population had criminal records before leaving the island. However, they found that some 40 percent of those individuals had been charged with offenses that would have been legal or classified as very minor violations in the United States. They also found that the vast majority of those with criminal records had already served their sentences and returned home by the time of the boatlift. See Hernández and Gomis pp. 138-40.

35 See M. Silva.
} 
trend, as the area had become a hub for the international cocaine trade in recent years. ${ }^{36}$ The participation of some Mariel Cubans in violent market competition associated with the illicit narcotics business did not go unnoticed in a national context where drugs and crime had ascended to the top of political agendas. ${ }^{37}$ Yet studies ultimately found that boatlift arrivals were "rarely overrepresented" in homicide rates despite news stories that depicted them as "high-rate killers" (Martinez, Jr. and Lee 500).

A set of events that unfolded alongside the boatlift further escalated the sense of emergency in South Florida leading up to the construction of Tent City. The previous winter, a group of police officers had viciously beaten a Black insurance agent named Arthur McDuffie after pursuing him in a high-speed chase. McDuffie died of his injuries four days later. In May of 1980, just a few weeks after the boatlift began, an allWhite jury acquitted four Dade County officers-three Anglos and one White Cuban-of all charges related to the McDuffie killing, including falsifying evidence. ${ }^{38}$ Black Miamians refused to allow the latest in a series of police abuses to go unchecked, and several neighborhoods erupted in pain and rage. Some people took to the streets in organized protests; some channeled their anger into attacks on passersby. A series of violent conflicts, both with police and among civilians, left 18 people dead and hundreds with severe injuries. ${ }^{39}$ The upheaval reinforced calls for a crackdown from Anglo leaders and members of the emerging Miami Cuban political class. By the end of the Summer, they were ready to "get tough" (McFarland 24 Jul.).

Migrants with limited options who ended up living in city parks or on the street were highly visible targets for those seeking a scapegoat, and Tent City became a potent symbol of a broader pattern of disorder. ${ }^{40} \mathrm{As}$ soon as the site opened, local and state officials began pressuring the federal government to take custody of the people housed there. In fact, the encampment may have reflected a deliberate tactic by Dade County and the City of Miami to dramatize their desire for federal intervention. Assistant City Manager Cesar Odio later admitted as much, claiming that local leaders had decided to build Tent City to pressure the Carter administration to take responsibility for Mariel Cubans without permanent shelter. ${ }^{41}$ In any case, under fire from municipal and state leaders, the federal government agreed to find alternative locations for the residents of Tent City so that they could shut down the site by the end of September. The people living there were expected to find sponsors or consent to be transferred to one of the "resettlement camps," which were starting to look and function more and more like prisons (Lipman 74-75). Some residents of Tent City decided they would rather find their own way than go back to confinement, so they walked out the gate and joined the ranks of houseless migrants in Miami.

\section{Local Jail, Federal Responsibility}

After Tent City closed, municipal leaders, including Odio and several other influential Cuban-born administrators, remained determined to get rid of the houseless newcomers. Police used public order charges, such as prohibitions on trespass and sleeping outside, to arrest Mariel migrants who did not comply with the city's plans for them. ${ }^{42}$ In the meantime, local officials continued to insist that the federal government should help.

Agents at the Miami Field Office of the Immigration and Naturalization Service (INS) were open to that idea. They knew that the parole status of the boatlift arrivals could be rescinded as quickly as it was granted, and they knew that the terms of parole required Mariel Cubans to maintain a means of support and a permanent residence. They claimed, though, that they lacked sufficient personnel to verify such information for everyone living on the street. ${ }^{43}$ In October, INS representatives met with Dade County and City of Miami administrators and four local police departments. They came out of their meeting with a plan. If police continued to arrest houseless Cubans using municipal ordinances, INS agents would attend court hearings and go to the Dade County Jail to identify people who had broken the terms of their parole. If agents concluded that a Mariel Cuban was guilty of such a violation, they could arrange to take that individual into federal custody. ${ }^{44}$

Elected officials and the mainstream press greeted news of the collaborative local-federal plan to take houseless Cubans off the streets with great enthusiasm. Miami newspapers had run dozens of articles and

\footnotetext{
${ }^{36}$ See Gootenberg pp. 166- 67.

37 See Kelly.

38 See López p. 157.

39 See Porter and Dunn pp. 47-73.

${ }^{40}$ For an important analysis of Tent City with a focus on representations of gay Cuban men in the encampment, see Peña pp. 61-67.

41 See Chardy.

42 See Arocha.

43 See Rivera.

44 See Morris.
} 
editorials condemning the Carter administration for policies that "dumped thousands of homeless newcomers onto the streets of Dade County's cities" amidst a recession and a housing crisis ("Dade Misled Again"). ${ }^{45}$ Business owners and politicians worried that the estimated 1,000-2,000 Mariel Cubans "wandering the streets" were repelling shoppers and tourists (Williams and Balmaseda). After the plan to arrest the houseless migrants was announced, Democratic U.S. Representative Claude Pepper told reporters that it represented "some real progress" in getting "these surplus, vagrant vagabonds off [the] streets" (Fiedler and Williams). By early December, an estimated 750 Mariel Cubans were in the Dade County Jail awaiting trial, mostly for alleged misdemeanors (Ligsukis 11 Dec.).

At first, though, the so-called "sweep" was more of a flop. The goal was to transfer 100-150 people from the jail to federal custody, but the INS initially found only 25 jailed Mariel Cubans eligible for parole revocation. The result reflected poor coordination between municipal and federal officials, as well as INS reluctance to expand its criteria for revoking parole. At the time, the agency could not accommodate a sudden influx of detainees because it had a limited infrastructure for confining noncitizens. ${ }^{46}$

This posed a serious problem for Dade County administrators, who were dealing with their own capacity problem. The County had been under a federal court order to reduce its jail population since long before the boatlift. In 1977, a partial summary judgment in the U.S. District Court for the Southern District of Florida set the maximum occupancy of the Dade County Jail at 895 people. In September 1980-before the "sweep" began-attorneys for the jail inmates filed a motion alleging that the County had fallen out of compliance with the court order. Judge Alcee Hastings responded a month later by calling for an immediate reduction in the jail population. At almost precisely the same moment, municipal leaders were initiating the scheme to round up Mariel Cubans and put them in the local jail. Once it became clear that the County had not followed his direction to fix the overcrowding problem, Hastings ordered them to restrict new jail admissions (Bridges v. Sandstrom). South Florida leaders immediately responded by claiming that Mariel Cubans were causing the overflow. They said that the federal government, not the county, was responsible. They seemed unbothered by the fact that they had explicitly directed local police to round up houseless migrants and put them in a jail that was already under a court order to reduce its population. ${ }^{47}$

Instead of taking accountability, Dade County got reinforcements. In February 1981, the Attorney General of Florida intervened in the case to file a complaint, naming Governor Bob Graham as a third-party plaintiff and the U.S. government as a defendant (Bridges v. Sandstrom). The complaint alleged that liability for overcrowding in the Dade County Jail lay with the U.S. Department of State-for its handling of the boatlift-and with the U.S. Department of Justice-because the INS had improperly paroled "excludable" migrants into the community and left Miami and Dade County to deal with them ("Suit in Florida"). ${ }^{48}$ The complaint called on the federal government to remove Mariel Cubans from the Dade County Jail and make the future use of parole for such migrants unlawful. A final demand in the complaint, which spoke to an issue that would become a persistent feature of debates over U.S. immigration policy, insisted that the federal government should compensate Dade County and the State of Florida for costs associated with confining noncitizens ("CHTF Director's Briefing Materials").

A lawsuit was hardly the only option available to local and state officials. Nor was the INS the only federal agency to offer assistance. In meetings with county and city administrators, employees of the Cuban-Haitian Task Force established by the Carter administration had firmly rejected the proposal for a mass roundup. They advocated a strategy focused on housing and jobs programs and highlighted the millions of federal dollars that soon would be granted to states and municipalities affected by the boatlift through an amendment to the Refugee Education Assistance Act, which had been pushed by the Florida Congressional delegation. ${ }^{49}$ Task Force staffers argued that making arrests would hamper their ability to find places for houseless

\footnotetext{
${ }^{45}$ As Connolly has shown, for many of its residents, Miami was always in the midst of a housing crisis.

46 See Williams and Arocha.

47 In fact, Dade County commissioned a study that undercut its own argument that the boatlift had caused the overcrowding. Of some 1050 inmates in late-December 1980, 103 were Mariel Cubans. If the INS had taken all of them into custody immediately, the number of inmates still would have exceeded the cap of 895 people set by the federal court order. See Unzueta.

48 Prior to 1996, U.S. immigration laws differentiated between "deportable" and "excludable" noncitizens. The latter category referred to individuals deemed ineligible for entry to the United States. This status reflected what legal scholars have termed the "entry fiction" - the concept that the rights of certain of noncitizens residing within the country were limited in ways akin to those of someone seeking admission from the outside. See Miller 631n98. The "entry fiction" contributed to the legal vulnerability of Mariel Cubans who passed into the U.S. under the parole mechanism of the Immigration and Nationality Act. They did not have the same legal standing as migrants officially admitted to the country, and Immigration Courts retroactively categorized as "excludable" many of those who acquired criminal convictions while living the United States.

49 See Loescher and Scanlan p. 186.
} 
Cubans. People caught up in the sweep were not likely to be deported for minor misdemeanors and would instead be funneled back into the federal resettlement system. The Carter administration officials worried that they would struggle to find new placements for people who had been rounded up in Miami, because potential sponsors were reluctant to take in someone whose immigration parole had been revoked as a result of a criminal charge or conviction. They also worried that the scheme could lead to abuses and potential civil rights lawsuits. ${ }^{50}$ Yet when presented with these alternatives, South Florida officials chose policing and incarceration instead. They wanted the federal government to get rid of houseless Mariel Cubans, not help them find their feet in Miami.

The specific dispute between the State of Florida and the U.S. government over the Dade County Jail was short-lived. In July 1981, a judge dismissed the third-party complaint against the federal government with the consent of both parties (Bridges $v$. Sandstrom). But the general issue at the center of that case did not go away. Just a few months later, a semiannual grand jury impaneled by the State Attorney in Miami began investigating the topics of "Immigration and Narcotics Interdiction." In a report filed the following spring, the Dade County Grand Jury presented "a record of failure on the part of the federal government" following the arrival of Cubans and Haitians in 1980. The authors of the report also decried "the federal failure to stem the flow of illegal aliens" and to "deport them once they have come" (Dade County, Grand Jury 4). The members of the Grand Jury claimed that INS lacked "the manpower and the ability to identify illegal aliens who [were] arrested for and convicted of felonies and who [were] sitting in the Dade County Jail at taxpayers' expense when they should be deported" (24). In addition to the issue of overcrowding at the jail, the Grand Jury emphasized connections between unauthorized immigration and the illicit drug trade. The members contended that South Florida suffered from the "twin problems" of "refugees and narcotics" (25). In both respects, they claimed, the federal government had failed to fulfill its responsibility to enforce the law, and local communities were suffering as a result.

The conflation of "illegal aliens" and "illegal drugs" was not a novel development, but it resonated in powerful new ways in the early-1980s. Miami was a key site in this national process, and converging fears about unauthorized migration, drugs, and crime had direct implications for U.S. immigration law. The members of the Grand Jury channeled their anxiety about the dual movement of undetected migrants and narcotics through South Florida into recommendations for more law enforcement funding. Vice President George Bush had recently announced the creation of a South Florida narcotics task force to integrate local and federal law enforcement efforts, but the authors of the report insisted that "[n]o drug interdiction effort will be successful unless it also interdicts the flow of illegal aliens" (28). They were especially worried that there were insufficient funds for "the INS investigative unit charged with the responsibility of identifying illegal aliens" already living in the United States (32). The members of the Grand Jury called for a system to enable local police to communicate directly with the INS about criminal suspects whose immigration status was in question, and they recommended tripling the size of the INS Investigations Division in Miami (39). In short, the report presented a vision for expanding and further intertwining the work of immigration and criminal law enforcement agencies at the local level.

On the topic of crime, the Grand Jury singled out Mariel Cubans, though the arrival of tens of thousands of Haitians on boats during the same period had contributed to the sense of crisis pervading South Florida. Both Haitians and Cubans faced intense reaction, and Haitian asylum seekers suffered especially long periods in detention. During the 1970s, Haitian organizations in the U.S. had decried the detention and deportation of their compatriots who were arriving in search of refuge. By the time of the simultaneous sea migrations in 1980, the Congressional Black Caucus was actively criticizing the exclusion of Haitians as a form of racial discrimination against Black refugees. ${ }^{51}$ While many Mariel Cubans were Black or mulato, the low number of Cubans of African descent already living in Miami had contributed to a perception in the U.S. that Cubans were a "White" group. Almost all the Cubans already established in Miami, moreover, had benefited from a uniquely favorable set of immigration policies. This left few organized groups prepared to recognize the particular challenges facing Black and mulato Mariel Cubans who, like Haitians, lacked refugee status. On the other hand, the persistent advocacy of Haitians and their allies appears to have helped convince the Dade County Grand Jury that the INS should suspend its "expensive and cruel" detention of Haitians. The Grand Jury suggested replacing Haitians, who constituted "a minuscule percentage of arrests" and posed "no danger" to the community, with a group that they saw as entirely deserving of imprisonment: "Mariel criminals" (24).

Although the members of the Grand Jury criticized the "very negative and generally inaccurate stereotype" ascribed to Mariel Cubans, they effectively reproduced it by marking a subset of the boatlift Cubans as emblematic of their apprehensions about migrants and crime (21). They argued that instead of holding

\footnotetext{
50 See Ligsukis 21 Nov.; Ligsukis 11 Dec

51 See Lindskoog p. 19, pp. 34-42.
} 
Haitians in its detention center off Krome Avenue to the west of Miami, the INS should "allocate its resources to create a linkage with Dade's criminal justice system" and go about "getting on with the real business of dealing with the many thousands of criminal illegal aliens and Mariel entrants who are crowding our jails and walking our streets. Krome can then be used to incarcerate these Mariel criminals and illegal aliens who are taken into federal custody" (24). ${ }^{52}$ Despite some efforts to avoid the distortions found in sensationalist news coverage, the members of the Grand Jury created yet another document that cast boatlift arrivals as noteworthy criminals.

\section{Scaling Up}

Governor Bob Graham and other Florida political leaders took many of the concerns articulated in the Grand Jury report to Washington. In the process, they created links with the demands of representatives from other states to produce what geographers Jenna M. Loyd and Alison Mountz describe as a "jump in scale" (131). When Graham spoke to Congress about the need for federal action on immigration in 1981, he did so on behalf of his counterparts from around the country as a representative of the National Governors' Association. His selection by that group was significant because, up to that point, Texas, California, and the New York City area had been forerunners in policies targeting unauthorized immigrants. ${ }^{53}$ Republican Representative Dan Lungren of California noted this regional shift in a subsequent Congressional hearing. "In California and the Southwest, per capita, in terms of the total numbers of illegal aliens, we have far more than any other region," he said. Lungren claimed that the resulting disquietude went largely unheeded, however, until Florida joined the conversation. "When it was merely a Southwest experience," he said, "there appeared to be very little action in other parts of the country toward moving on the immigration issue. Unfortunately, it took the Mariel boat crisis to make it a more nationalized issue" (Immigration Reform and Control Act of 1983 166). Such remarks belied the extent to which prejudices against Mexicans and demands from border states had long driven immigration policy. ${ }^{54}$ There is little doubt, however, that the Mariel Boatlift riveted national attention to these questions and provided advocates of restriction with the increasingly recognizable figure of the "criminal alien" at a pivotal moment. ${ }^{55}$

During the same Congressional hearings in which Graham demanded federal action on "illegal criminal aliens," Republican Senator Alan Simpson of Wyoming announced his intention to work with Democratic Representative Romano Mazzoli of Kentucky to lead an overhaul of U.S. immigration law (Final Report of the Select Commission 2). In hearings on their proposed bill a year later, Graham again appeared before Senate and House subcommittees to call for a federal "contingency plan" for future "unanticipated flows" of migrants. ${ }^{56} \mathrm{He}$ also demanded provisions in the legislation to force the U.S. Attorney General to revoke parole for migrants convicted of a felony or three misdemeanors (Immigration Reform and Control Act of 1982 106-7). In 1983 hearings on what was then known as the "Simpson-Mazzoli bill," Republican Florida Senator Paula Hawkins pushed for federal funding for states and municipalities forced to deal with a "Marieltype disaster." She specifically mentioned the impact of the boatlift on the criminal legal system in Dade County (Immigration Reform and Control Act 9). And she supported a plan to reimburse states for the cost of imprisoning noncitizens convicted of felonies. ${ }^{57}$ Three years after that, Ronald Reagan signed the bill into law as the Immigration Reform and Control Act of 1986 (IRCA).

IRCA bears clear traces of the demands of Florida lawmakers. The legislation is often remembered for creating a mechanism for several million undocumented people in the U.S. to gain legal status and for criminalizing the employment of undocumented workers. But several of its lesser-known provisions echoed

\footnotetext{
${ }^{52}$ The Dade County Grand Jury may have seen Krome as a potential site for long-term confinement, but it is more likely that they viewed it as a holding place that the INS could use prior to deporting Mariel Cubans with criminal records. Their report suggests that the members of the Grand Jury had a limited understanding of the difficulty of maintaining a repatriation agreement between Cuba and the United States, a complication that ultimately led the U.S. government to indefinitely confine thousands of Mariel migrants during the 1980s. On those diplomatic negotiations, see Kami.

${ }^{53}$ See Cox and Miles p. 92; Denvir pp. 36-41.

${ }^{54}$ See Lytle Hernández, Migra!; Goodman.

${ }^{55}$ There was no more prominent personification of the concept of the "criminal alien" in the 1980s than Tony Montana, the murderous Mariel Cuban protagonist in Oliver Stone's 1983 film, Scarface.

${ }^{56}$ Shull explains that, within a year of Graham's testimony, the Reagan administration had finalized a "Mass Immigration Emergency Plan," which "called for the location of new permanent detention sites to relieve overcrowding and as a contingency plan in the event of another mass migration like Mariel" (39). A trace of Graham's request also appears in the final clause of IRCA, which directs the Secretary of Defense to create a list of sites "that could be made available to the Bureau of Prisons for use in incarcerating aliens who are subject to exclusion or deportation from the United States" (Immigration Reform and Control Act 3445).

57 See Loyd and Mountz p. 132.
} 
the calls for dealing with "criminal" migrants that had emanated from Miami in the wake of the boatlift. IRCA directed the Attorney General to "begin any deportation proceeding as expeditiously as possible" after a conviction for a criminal charge, an acknowledgment of complaints from South Florida and elsewhere about the length of time that noncitizens spent in local jails and state prisons ("Immigration Reform and Control Act" 3445). The imprint of Florida lawmakers was especially evident in two other provisions of IRCA. While it did not go as far as some hoped, the legislation provided for the allocation of funds to reimburse states for costs associated with imprisoning unauthorized immigrants or any "Cuban national"-regardless of immigration status-who had been convicted of a felony. One astounding section of the law incorporated the condescending and pejorative nickname given to the Cubans from Mariel. The text explicitly named "Marielito Cubans convicted of a felony" as a group of people for whom the costs of imprisonment at the state level would be reimbursed (3443). Cubans who had arrived in the boatlift found themselves singled out for their criminality once again, this time in a major revision to U.S. immigration law.

Responses to Mariel in South Florida reverberated through federal policy in other clearly visible ways. During the early-1980s, the INS claimed that funding constraints limited its participation in anti-drug operations and its efforts to police migrants already living in the United States. War on Drugs legislation expanded the agency's resources and its reach. Mariel Cubans remained an important reference point as this process unfolded. In fact, at least one strategy the INS developed specifically for Mariel Cubans appears to have become a template for its new focus on people the agency classified as "criminal aliens." A 1986 INS Investigations Division report proposed expanding the use of what it called "Mariel Cuban criminal violator models" beyond districts where it had been "previously perfected." These initiatives entailed "mixed squad operations, characterized by active, shared participation by INS, local and state police tactical squads and narcotics units" ("Criminal Aliens" 304). This was precisely the sort of collaboration between local and federal law enforcement that many Miamians had demanded in the fall of 1980.

Although IRCA led to a significant increase in funding for policing migrants, its focus was on U.S. international borders. However, a piece of War on Drugs legislation signed just 10 days earlier allocated funds to the INS division that handled enforcement in the country's interior. The Anti-Drug Abuse Act of 1986 (ADAA) provided for the creation of a pilot program in four cities to improve computer networks between INS district offices and municipal police departments. These systems were supposed to enable federal agents to quickly identify noncitizens charged with drug offenses by local law enforcement (Anti-Drug Abuse Act 3207-48). Like IRCA, then, the ADAA reflected demands that had circulated in South Florida after the boatlift, where the Dade County Grand Jury called on the federal government to expand its ability to identify and take custody of noncitizens in local jails and state prisons.

The pilot project created through the ADAA became part of the emerging "Alien Criminal Apprehension Program" (ACAP) and marked the beginning of a new era of integrated efforts to police the mobility of transnational migrants in the United States. One of its first testing grounds was South Florida. The INS began the pilot project in Chicago, New York, Los Angeles, and Miami. ${ }^{58}$ Although its initial impact was limited, over the ensuing decades ACAP evolved and expanded to become a key element of the apparatus linking federal immigration enforcement agents with local and state police. ${ }^{59}$ In 2006, the recently created Department of Homeland Security merged ACAP with another unit to form the "Criminal Alien Program," which remains in place today. ${ }^{60}$ Agents from this unit are responsible for responding to 'hits' in a system established through a related program known as "Secure Communities." This massive information-sharing collaboration with the Federal Bureau of Investigation captures the biometric data of people arrested by local police throughout the country and flags potentially deportable people so that immigration agents can investigate. Miamians and their elected officials probably could not have imagined a program linking local police departments with federal agencies that operated on such a scale, but their report suggests that the members of the Fall 1981 Dade County Grand Jury would have been pleased with the result.

\section{Conclusion}

In 1987, the Florida State Attorney in Miami submitted a copy of that Grand Jury's report for inclusion in a Senate subcommittee hearing entitled, "Illegal Alien Felons: A Federal Responsibility." She noted in a cover letter that, six years after the boatlift, there was still no efficient way to determine a noncitizen's legal status upon arrest. "Most aliens and entrants pass through the justice system undetected," she wrote. That

\footnotetext{
${ }^{58}$ See Nelson pp. $177-78$.

59 See Schuck and Williams.

${ }^{60}$ See Lasch pp. 166-67; "The Criminal Alien Program (CAP)."
} 
State Attorney, Janet Reno, became U.S. Attorney General several years later (Reno). During her tenure she oversaw the implementation of the Illegal Immigration Reform and Immigrant Responsibility Act of 1996 (IIRIRA), which tightened the links between systems of immigration and criminal law enforcement and spurred a massive increase in detention and deportations. ${ }^{61}$ Crucial conceptual and legal groundwork for those developments was laid much earlier, during Reno's time in South Florida in the aftermath of Mariel. ${ }^{62}$

The fallout from the Mariel Boatlift contributed to important shifts in ideas about the primary aim of immigration enforcement. Kelly Lytle Hernández writes that in the 1950s, the imagined target of Border Patrol agents shifted from the "illegal alien" to the "criminal alien," a distinct subject produced in the context of the growing War on Drugs. ${ }^{63}$ During the 1980s, the "criminal alien" moved from the minds of law enforcement insiders to the public sphere as a fictive but widely recognizable figure, one frequently invoked in a bipartisan push for restrictive immigration legislation and in attempts to undermine calls for more expansive immigrant rights. ${ }^{64}$ While it was not the only site responsible for the growing emphasis on "criminal aliens" in U.S. immigration policy, Miami was of fundamental importance. ${ }^{65}$

A careful examination of Miami after the boatlift reveals that a focus on particular "types" of Mariel Cubans drove punitive responses in the press and in policymaking decisions. This group was at the center of the social, political, and legal processes that pushed U.S. immigration policy beyond a crucial inflection point. When Florida Governor Bob Graham testified before Congress and warned that the handling of the boatlift would encourage other nations to "dump their refuse on the United States," he had specific individuals in mind (Final Report of the Select Commission 117). He would have had clear memories of the people living in Tent City, the people rounded up on the streets of Miami, and the people confined in the Dade County Jail. The Mariel Cubans who ended up in jails and prisons in the U.S. were largely poor and working-class people. Many were Black or mulato. Tens of thousands were young men with past experiences of incarceration. All were living with the effects of precarious immigration status. A study of Mariel Cubans in Miami cannot explain everything about the growth in the criminalizing dimensions of U.S. immigration enforcement during the 1980s. Other key moments and places contributed to transformations in U.S. immigration policy during this period. These changes cannot be understood, however, without a study of small-scale dynamics in Miami or an account of the lives of the Mariel Cubans who became particular targets in a system that evolved to cast a much broader group of migrants as "criminals" amidst escalating efforts to police, confine, and exclude them.

\section{Acknowledgements}

Archival research for this project was made possible by the Program in Race, Law, and History at the University of Michigan Law School. The author would like to acknowledge generous feedback on draft versions or sections of this article provided by Paulina Alberto, Stacey Bishop, Sam Erman, Miranda García, David Helps, Jesse Hoffnung-Garskof, Matthew Lassiter, Nicole Navarro, Silvia Pedraza, Gerson Rosales, Elena Rosario, Rebecca Scott, Jennifer Triplett, and Kerry White, as well as the reviewers and editors of this special issue.

\section{Competing Interests}

The author has no competing interests to declare.

\section{References}

Anti-Drug Abuse Act of 1986. Pub. L. No. 99-570, 100 Stat. 3207-3207-192 (1986). U.S. Government Publishing Office, www.govinfo.gov/content/pkg/STATUTE-100/pdf/STATUTE-100-Pg3207.pdf. Accessed 30 Apr. 2021.

Arboleya, Carlos J. “Cuban Influx: Miami’s Explosive Blessing." Miami Herald, 8 Jun. 1980, pp. 4E-5E.

\footnotetext{
61 See Goodman pp. 176-79.

${ }^{62}$ Like Reno, President Bill Clinton had a direct connection to the Mariel Boatlift. He was in his first term as Governor of Arkansas when the Carter administration decided to consolidate "hard-to- sponsor" Mariel Cubans at Fort Chaffee, in the northwest corner of the state. His opponent exploited Arkansans' resentment of this decision during the 1980 campaign and handed Clinton his sole electoral defeat as an incumbent. See Moyer.

${ }^{63}$ See Lytle Hernández, "Amnesty or Abolition?" Ngai has described the earlier emergence of the "illegal alien" as a "legal and political subject" (4).

${ }^{64}$ Loyd and Mountz track a similar trajectory through the machinations of elected officials, including Democratic Governor (and, later, Senator) Bob Graham of Florida and Republican Senator Alfonse D'Amato of New York. D'Amato sought to link what he described as the "national prison overcrowding crisis" in the early-1980s to the presence of "alien felons" in prisons in certain states. He singled out Mariel Cubans as a "sizeable criminal class" (qtd. in Loyd and Mountz 129-31). By the 1990s, the figure of the "criminal alien" was increasingly invoked by politicians as a key target of federal immigration legislation (135).

65 See Felker-Kantor.
} 
Arocha, Zita. "Arrested Refugees Given Last Chance." Miami Herald, 28 Sep. 1980, p. 16A.

Bach, Robert L., et al. "The Flotilla 'Entrants': Latest and Most Controversial." Cuban Studies, vol. 11, no. 2, 1981, pp. 29-48.

Bon Tempo, Carl J. Americans at the Gate: The United States and Refugees during the Cold War. Princeton University Press, 2008. DOI: https://doi.org/10.1515/9781400829033

Bridges v. Sandstrom, No. 74-994-CIV, (S.D. Fla.). Docket sheet (in author's possession).

Bronfman, Alejandra. Measures of Equality: Social Science, Citizenship, and Race in Cuba, 1902-1940. University of North Carolina Press, 2004. DOI: https://doi.org/10.1525/jlat.2005.10.2.469

Bustamante, Michael J. Cuban Memory Wars: Retrospective Politics in Revolution and Exile. The University of North Carolina Press, 2021.

Capó, Jr., Julio. "Queering Mariel: Mediating Cold War Foreign Policy and U.S. Citizenship among Cuba's Homosexual Exile Community, 1978-1994." Journal of American Ethnic History, vol. 29, no. 4, 2010, pp. 78-106. DOI: https://doi.org/10.5406/jamerethnhist.29.4.0078

Carter, Jimmy. "League of Women Voters Remarks and a Question and Answer Session at the League's Biennial." 5 May 1980. The American Presidency Project, www.presidency.ucsb.edu/documents/league-womenvoters-remarks-and-question-and-answer-session-the-leagues-biennial-national. Accessed 4 Apr. 2021.

Chacón, Jennifer M. "Managing Migration through Crime." Columbia Law Review Sidebar, vol. 109, 2009, pp. 135-48. DOI: https://doi.org/10.2139/ssrn.2033931

Chardy, Alfonso. "El Mariel cambió la historia de Miami." El Nuevo Herald, 24 Apr. 2010, www.elnuevoherald. com/noticias/especiales/mariel-es/article2004747.html. Accessed 30 Apr. 2021.

"CHTF Director's Briefing Materials for the Senate Appropriations Committee Hearings Held During the Week of March 2, 1981." 1981. Records of the Cuban-Haitian Task Force. Record Group 220, Subject Files, Box 4, Folder "Hearing Transcript and Briefing Book 1." Jimmy Carter Presidential Library, Atlanta, GA (hereafter JCPL).

Clark, Juan, et al. The 1980 Mariel Exodus: An Assessment and Prospect. Special Report, Council for InterAmerican Security, 1981.

"Comprehensive U.S. Action a Must for Cuban Refugees." Miami Herald, 7 Aug. 1980, p. 6A.

Connolly, N. D. B. A World More Concrete: Real Estate and the Remaking of Jim Crow South Florida. University of Chicago Press, 2014. DOI: https://doi.org/10.7208/chicago/9780226135250.001.0001

Cox, Adam B., and Thomas J. Miles. "Policing Immigration." The University of Chicago Law Review, vol. 80, no. 1, 2013, pp. 87-136.

"Criminal Aliens: A Report to the Committee on Appropriations, United States Senate." Emerging Criminal Groups, United States, Congress, Senate, Committee on Governmental Affairs, 17 and 24 Sep. 1986. U.S. Government Printing Office, 1987, pp. 261-309.

Dade County, Grand Jury, Fall Term 1981. "Immigration and Narcotic Interdiction," Final Report of the Grand Jury. Circuit Court of the Eleventh Judicial Circuit of Florida for the County of Dade, 11 May 1982, miamisao.com/wp-content/uploads/2021/02/gj1981f4.pdf. Accessed 30 Apr. 2021.

"Dade Misled Again on Refugees." Miami Herald, 29 Nov. 1980, p. 6A.

de la Fuente, Alejandro. A Nation for All: Race, Inequality, and Politics in Twentieth-Century Cuba. University of North Carolina Press, 2001.

del Castillo, Siro. "A Plea to Destigmatize Mariel." Caribbean Review, translated by Judith C. Faerron, vol. XIII, no. 4, 1984, p. 7.

Denvir, Daniel. All-American Nativism. Verso, 2020.

Dewar, Heather. "Thunderstorm Heads for Straights, 250 Boats Urged to Make for Port." Miami News, 2 May 1980, p. 1A.

Dow, Mark. American Gulag: Inside U.S. Immigration Prisons. University of California Press, 2005. DOI: https://doi.org/10.1525/9780520939271

Duany, Jorge. "Cuban Communities in the United States: Migration Waves, Settlement Patterns and Socioeconomic Diversity." Pouvoirs Dans La Caraïbe, vol. 11, 1999, pp. 69-103. DOI: https://doi.org/10.4000/plc.464

Felker-Kantor, Max. Policing Los Angeles: Race, Resistance, and the Rise of the LAPD. University of North Carolina Press, 2018. DOI: https://doi.org/10.5149/northcarolina/9781469646831.001.0001

Fiedler, Tom, and Dan Williams. "U.S. Will Assume Custody of Refugees Held in Jails." Miami Herald, December 11, 1980, p. 1A.

García Hernández, César Cuauhtémoc. "Creating Crimmigration." Brigham Young University Law Review, vol. 2013, no. 6, p. 60. 
García, María Cristina. Havana USA: Cuban Exiles and Cuban Americans in South Florida, 1959-1994. University of California Press, 1996.

Goodman, Adam. The Deportation Machine: America's Long History of Expelling Immigrants. Princeton University Press, 2020. DOI: https://doi.org/10.23943/princeton/9780691182155.001.0001

Gootenberg, Paul. "Cocaine's Long March North, 1900-2010." Latin American Politics and Society, vol. 54, no. 1, 2012, pp. 159-80. DOI: https://doi.org/10.1111/j.1548-2456.2012.00146.x

Gosin, Monika. The Racial Politics of Division: Interethnic Struggles for Legitimacy in Multicultural Miami. Cornell University Press, 2019. DOI: https://doi.org/10.1515/9781501738258

Guerrero, Perla. Nuevo South: Latinas/os, Asians, and the Remaking of Place. University of Texas Press, 2017. DOI: https://doi.org/10.7560/313640

Hamm, Mark S. The Abandoned Ones: The Imprisonment and Uprising of the Mariel Boat People. Northeastern University Press, 1995.

Hardman, Scott L. Memorandum to Christian R. Holmes. 7 Aug. 1980. Records of the Cuban-Haitian Task Force. Record Group 220, Subject File, Box 9, Folder "Tent City." JCPL.

Hartzell, Anne B. Letter to the Editor. Miami Herald, 4 Jun. 1980, p. 6A.

Hernández, Rafael, and Redi Gomis. "Retrato del Mariel: El ángulo socioeconómico." Cuadernos de Nuestra América, vol. 3, no. 5, 1986, pp. 124-51.

Hinton, Elizabeth Kai. From the War on Poverty to the War on Crime: The Making of Mass Incarceration in America. Harvard University Press, 2016. DOI: https://doi.org/10.4159/9780674969223

Hirota, Hidetaka. Expelling the Poor: Atlantic Seaboard States and the Nineteenth-Century Origins of American Immigration Policy. Oxford University Press, 2017. DOI: https://doi.org/10.1093/acprof: oso/9780190619213.001.0001

Hoeffel, Paul Heath. "Fort Chaffee's Unwanted Cubans." New York Times Magazine, 21 Dec. 1980, p. 30-31, 42-54.

Hufker, Brian, and Gray Cavender. "From Freedom Flotilla to America's Burden: The Social Construction of the Mariel Immigrants." Sociological Quarterly, vol. 31, no. 2, June 1990, pp. 321-35. DOI: https://doi. org/10.1111/j.1533-8525.1990.tb00331.x

Immigration and Nationality Act. Pub. L. No. 414, 66 Stat. 163-282 (1952). U.S. Government Publishing Office, www.govinfo.gov/content/pkg/STATUTE-66/pdf/STATUTE-66.pdf. Accessed 29 Apr. 2021.

Immigration Reform and Control Act of 1986. Pub. L. No. 99-603, 100 Stat. 3359-3445 (1986). U.S. Government Publishing Office, www.govinfo.gov/content/pkg/STATUTE-100/pdf/STATUTE-100-Pg3445.pdf. Accessed 30 Apr. 2021.

Kahn, Robert S. Other People's Blood: U.S. Immigration Prisons in the Reagan Decade. Westview Press, 1996.

Kami, Hideaki. Diplomacy Meets Migration: US Relations with Cuba during the Cold War. Cambridge University Press, 2018. DOI: https://doi.org/10.1017/9781108526043

Kelly, James. "Trouble in Paradise." Time, 23 Nov. 1981, pp. 22-32.

Kohler-Hausmann, Julilly. Getting Tough: Welfare and Imprisonment in 1970s America. Princeton University Press, 2017. DOI: https://doi.org/10.23943/princeton/9780691174525.001.0001

Lai, Annie. "Confronting Proxy Criminalization." Denver University Law Review, vol. 92, no. 4, 2015 , pp. 879-908.

Lasch, Christopher N. "Enforcing the Limits of the Executive's Authority to Issue Immigration Detainers." William Mitchell Law Review, vol. 35, no. 1, 2008, pp. 164-96.

Ligsukis, Sylvester. Memorandum to Frederick Bohen. 21 Nov. 1980. Records of the Cuban-Haitian Task Force. Record Group 220, Fort Indiantown Gap Camp Files, Box 36, Folder "INS 1." JCPL.

Ligsukis, Sylvester. Memorandum to Frederick Bohen. 11 Dec. 1980. Records of the Cuban-Haitian Task Force. Record Group 220, Fort Indiantown Gap Camp Files, Box 36, Folder "INS 1." JCPL.

Lindskoog, Carl. Detain and Punish: Haitian Refugees and the Rise of the World's Largest Immigration Detention System.University of Florida Press, 2018.DOI:https://doi.org/10.5744/florida/9781683400400.001.0001

Lipman, Jana K. "A Refugee Camp in America: Fort Chaffee and Vietnamese and Cuban Refugees, 19751982." Journal of American Ethnic History, vol. 33, no. 2, 2014, pp. 57-87. DOI: https://doi.org/10.5406/ jamerethnhist.33.2.0057

Loescher, Gil and John A. Scanlan. Calculated Kindness: Refugees and America's Half-Open Door, 1945-Present. The Free Press, 1986.

López, Antonio M. Unbecoming Blackness: The Diaspora Cultures of Afro-Cuban America. New York University Press, 2012. DOI: https://doi.org/10.18574/nyu/9780814765463.001.0001 
Loyd, Jenna M., and Alison Mountz. Boats, Borders, and Bases: Race, the Cold War, and the Rise of Migration Detention in the United States. University of California Press, 2018. DOI: https://doi.org/10.1525/ california/9780520287969.001.0001

Lytle Hernández, Kelly. "Amnesty or Abolition?" Boom: A Journal of California, vol. 1, no. 4, 2011, pp. 54-68. DOI: https://doi.org/10.1525/boom.2011.1.4.54

---. City of Inmates: Conquest, Rebellion, and the Rise of Human Caging in Los Angeles, 1771-1965. University of North Carolina Press, 2017.

---. Migra!: A History of the U.S. Border Patrol. University of California Press, 2010.

Martinez, Jr., Ramiro, and Matthew T. Lee. "On Immigration and Crime." Criminal Justice 2000: Vol. 1 The Nature of Crime: Continuity and Change, U.S. Department of Justice, 2000, pp. 485-524.

McFarland, Beverly. News Segment. 25 Apr. 1980. WTVJ Newstape Cut Stories. 249. Wolfson Florida Moving Image Archives, Miami Dade College Archives, Miami, FL (hereafter Wolfson Archives), streaming.mdc. edu/streaming/249.MP4. Accessed 29 Apr. 2021.

McFarland, Beverly. News Segment. 24 Jul. 1980. WTVJ Newstape Cut Stories. 273. Wolfson Archives, streaming.mdc.edu/streaming/273.MP4. Accessed 30 Apr. 2021.

Miller, Teresa A. "Citizenship \& Severity: Recent Immigration Reforms and the New Penology." Georgetown Immigration Law Journal, vol. 17, no. 4, 2003, pp. 611-66.

Mirabal, Nancy Raquel. “'Ser de Aquí': Beyond the Cuban Exile Model.” Latino Studies, vol. 1, no. 3, 2003, pp. 366-82. DOI: https://doi.org/10.1057/palgrave.lst.8600044

Morris, Raymond A. Letter to James Gigante. 1 Oct. 1980. Cuban Refugee Center Records. CHC 0218, Series II, Box 24, Folder 125. Cuban Heritage Collection, University of Miami, Coral Gables, FL.

Motomura, Hiroshi. "The Discretion That Matters: Federal Immigration Enforcement, State and Local Arrests, and the Civil-Criminal Line." UCLA Law Review, vol. 58, no. 6, 2011, pp. 1819-58.

Moyer, Justin Wm. "The forgotten story of how refugees almost ended Bill Clinton's career." Washington Post, 17 Nov. 2015, www.washingtonpost.com/news/morning-mix/wp/2015/11/17/the-forgotten-story-ofhow-refugees-almost-ended-bill-clintons-career/. Accessed 30 Apr. 2021.

Muhammad, Khalil Gibran. The Condemnation of Blackness: Race, Crime, and the Making of Modern Urban America. Harvard University Press, 2010. DOI: https://doi.org/10.2307/j.ctvjsf4fx

Nelson, Alan. "Statement of the Commissioner Alan C. Nelson before the Subcommittee on Immigration and Refugee Affairs." Authorization Legislation and Oversight of the U.S. Department of Justice (Civil Rights Division and INS): Hearings on the Department of Justice Authorization Act for Fiscal Year 1988, United States, Congress, Senate, Committee on the Judiciary, 10 and 24 Mar. 1987. U.S. Government Printing Office, 1988, pp. 169-78.

Ngai, Mae M. Impossible Subjects: Illegal Aliens and the Making of Modern America. Princeton University Press, 2004.

O'Connor, Alice. Poverty Knowledge: Social Science, Social Policy, and the Poor in Twentieth-Century U.S. History. Princeton University Press, 2001. DOI: https://doi.org/10.1515/9781400824748

"Overview: Resettlement Camps, Chapter 2." 25 Sep. 1981. Fort Chaffee Collection. CHC 5175, Box 1, Folder 1. CHC.

Parker, Kunal Madhukar. Making Foreigners: Immigration and Citizenship Law in America, 1600-2000. Cambridge University Press, 2015. DOI: https://doi.org/10.1017/CB09781139343282

Pear, Robert. "Cuban Aliens, but Not Haitians, Will be Offered Residency Status." New York Times, 12 Feb. 1984, p. 1.

Pedraza, Silvia. Political Disaffection in Cuba's Revolution and Exodus. Cambridge University Press, 2007.

Peña, Susana. iOye Loca!: From the Mariel Boatlift to Gay Cuban Miami. University of Minnesota Press, 2013. DOI: https://doi.org/10.5749/minnesota/9780816665532.001.0001

Porter, Bruce, and Marvin Dunn. The Miami Riot of 1980: Crossing the Bounds. Lexington Books, 1984.

Portes, Alejandro, and Alex Stepick. City on the Edge: The Transformation of Miami. University of California Press, 1993.

Putnam, George. Memorandum to Roger Winter. 2 May 1980. Records of the Cuban-Haitian Task Force. Record Group 220, Subject Files, Box 1, Folder “Cuban Situation: Daily Reports - Miami." JCPL.

Refugee Act of 1980. Pub. L. No. 96-212, 94 Stat. 102-118 (1980). U.S. Government Publishing Office, uscode. house.gov/statutes/pl/96/212.pdf. Accessed 29 Aug. 2021.

Renick, Ralph. Editorial. 1 May 1980. WTVJ Newstape Cut Stories. 250. Wolfson Archives, streaming.mdc. edu/streaming/250.MP4. Accessed 29 Apr. 2021. 
Reno, Janet. Letter to Donald L. Willey. 19 Nov. 1986. Illegal Alien Felons: A Federal Responsibility, United States, Congress, Senate, Committee on Governmental Affairs, 12 Mar. 1987. U.S. Government Printing Office, 1988, pp. 40-41.

Rios, Victor M. Punished: Policing the Lives of Black and Latino Boys. New York University Press, 2011.

Rivera, Mario A. Report. 6 Aug. 1980. Records of the Cuban-Haitian Task Force. Record Group 220, Subject File, Box 9, Folder “Tent City." JCPL.

Rodríguez, Cristina M. "The Significance of the Local in Immigration Regulation." Michigan Law Review, vol. 106, no. 4, 2008, pp. 567-642.

Rose, Willard P. "Soldiers in the Dark on Riot Orders." Miami Herald, 3 Jun. 1980, p. 1A.

Schuck, Peter H., and John Williams. "Removing Criminal Aliens: The Pitfalls and Promises of Federalism." Harvard Journal of Law \& Public Policy, vol. 22, no. 2, 1999, pp. 367-463.

Shull. "Reagan's Cold War on Immigrants: Resistance and the Rise of a Detention Regime, 1981-1985." Journal of American Ethnic History, vol. 40, no. 2, 2021, pp. 5-51. DOI: https://doi.org/10.5406/ jamerethnhist.40.2.0005

Sierra Madero, Abel. “'Here, Everyone's Got Huevos, Mister!': Nationalism, Sexuality, and Collective Violence in Cuba during the Mariel Exodus." The Revolution from Within: Cuba, 1959-1980, Duke University Press, 2019, pp. 244-74. DOI: https://doi.org/10.1215/9781478004325-011

Silva, John, and Tom Dubocq. "State to Open 2 Missile Sites Here for Exiles." Miami News, 6 May 1980, p. 1A. DOI: https://doi.org/10.21112/ita.1980.1.6

Silva, Mark. "Castro's Ex-Cons Blamed for Tide of Beach Crime." Miami Herald, 7 Aug. 1980, p. 2C.

Stabile, Carol A. White Victims, Black Villains: Gender, Race and Crime News in US Culture. Routledge, 2006.

Stark, Nathan J. Memorandum to Jack Watson. 18 Jun. 1980. Records of the Cuban-Haitian Task Force. Record Group 220, Subject File, Box 1, Folder "Cuban Situation - Reports to the White House." JCPL.

"Status Report - Fort Chaffee." June 1981. Fort Chaffee Collection. CHC 5175, Box 1, Folder 5. CHC.

Stone, Oliver. Scarface. Universal Studios, 1983.

Stumpf, Juliet. "States of Confusion: The Rise of State and Local Power over Immigration." North Carolina Law Review, vol. 86, no. 6, 2008, pp. 1557-618.

--- "The Crimmigration Crisis: Immigrants, Crime, and Sovereign Power." American University Law Review, vol. 56, no. 2, 2006, pp. 367-420.

"Suit in Florida Challenges U.S. Release of Refugees." New York Times, 7 Feb. 1981, p. 6.

"The Criminal Alien Program (CAP): Immigration Enforcement in Prisons and Jails." American Immigration Council, 1 Aug. 2013, www.americanimmigrationcouncil.org/research/criminal-alien-program-cap-immigrationenforcement-prisons-and-jails.

United States, Congress, House \& Senate, Committees on the Judiciary. Final Report of the Select Commission on Immigration and Refugee Policy. 5, 6, and 7 May 1981. U.S. Government Printing Office, 1981.

---. Immigration Reform and Control Act of 1982: Joint Hearings on H.R. 5872 and S. 2222. 1 and 20 Apr. 1982. U.S. Government Printing Office, 1982.

United States, Congress, House, Committee on the Judiciary. Immigration Reform and Control Act of 1983: Hearings on H.R. 1519. 1, 2, 9, 10, 14, and 16 Mar. 1983. U.S. Government Printing Office, 1983.

United States, Congress, Senate, Committee on the Judiciary. Immigration Reform and Control Act: Hearings on S. 529. 24, 25, and 28 Feb. and 7 Mar. 1983. U.S. Government Printing Office, 1983.

Unzueta, Silvia M. "Study of Hispanic Inmates at the Three Metro Dade County Correction and Rehabilitation Facilities." Office of the County Manager, Dade County, FL, 31 Dec. 1980.

Veciana, Ana. "Outlook's Dim for Exiles Wanting to Stay in Dade." Miami News, 12 May 1980, p. 1A.

Will, George F. "A Nation of Emigrants." Washington Post, 27 Apr. 1980, p. F7. Williams, Dan, and Zita Arocha. "Round of Homeless Refugees Flops." Miami Herald, 12 Dec. 1980, p. 1B.

Williams, Dan, and Liz Balmaseda. "City Pleads for Help With 2,000 Vagrant Refugees." Miami Herald, 12 Dec. 1980, p. 3B.

Young, Elliott. Forever Prisoners: How the United States Made the World's Largest Immigrant Detention System. Oxford University Press, 2021. DOI: https://doi.org/10.1093/oso/9780190085957.001.0001 
How to cite this article: Stephens, AM 2021 Making Migrants "Criminal": The Mariel Boatlift, Miami, and U.S. Immigration Policy in the 1980s. Anthurium, 17(2): 4, 1-18. DOI: https://doi.org/10.33596/anth.439

Published: 14 December 2021

Copyright: (c) 2021 The Author(s). This is an open-access article distributed under the terms of the Creative Commons Attribution 4.0 International License (CC-BY 4.0), which permits unrestricted use, distribution, and reproduction in any medium, provided the original author and source are credited. See http://creativecommons.org/licenses/by/4.0/. 